DOI 10.4467/2543733XSSB.17.006.9981

\author{
L'UBICA HARBUL'OVÁ \\ Instytut Historii \\ Uniwersytet Preszowski w Preszowie
}

\title{
ROZWÓJ WYDARZEŃ NA SYBERII W LATACH 1917-1919 I MIEJSCE W TYM PROCESIE LEGIONU CZECHOSLOWACKIEGO
}

\author{
The Development of the Events in Siberia in 1917-1919 \\ and the Place in this Process of the Czechoslovak legion
}

Summary

Siberia occupied a specific position in Russian history. In Tsarist Russia, it was the region with the largest area, however, sparsely populated and poorly understood.

Siberia, however, had the opinion of a region with a tendency to separatism. This was favoured by its geographical location as well as the specificity of its economic development and the way of administering the area.

All these factors created favourable conditions for the emergence of "specific" moods among urban intelligentsia, which in the nineteenth century contributed to the emergence of the Siberian regional movement ("oblastniczestwo"). The Siberian regional movement was created in the $19^{\text {th }}$ century, and its basis formed an idea conditioned by the specificity of Siberia.

The ideas of the Siberian regional movement, however, did not find much support among the citizens of Siberia and the local intelligentsia. The beginning of the twentieth century brought a revival of the regional movement in Siberia. The events in St. Petersburg in 1917 also activated the Siberian regionalists. The events taking place in the European part of Russia were a signal to increase the efforts and activities of the Siberian regionalists who at that time became the main promoters of the idea of Siberian autonomy. In October 1917, the postulate of the autonomy of Siberia was formulated during the Siberian Regional Meeting, and in December 1917, the Siberian Circuit Convention adopted a resolution on the creation of temporary administrative bodies, which were to become the Siberian Duma District and the Siberian District Council.

The Bolsheviks' arrival in power in January 1918 interrupted the activities of the Siberian autonomous authorities. In June 1918, the Bolsheviks were forsaken from the Siberian cities, and the Siberian Provisional Government and the Siberian Duma District came to power.

During this period, Czechoslovak legion played an important role in internal events in Siberia.

The legion leaders made contact with the Siberian Provisional Government and representatives of the Siberian Central Duma. In time, legion actively participated in internal political events that continued in Siberia up to 1920. 
Keywords: Siberia, autonomous authorities, 1917-1919, Czechoslovak legion

Słowa kluczowe: Syberia, autonomiczne organy władzy, lata 1917-1919, Legion Czechosłowacki

Syberia zajmowała w historii Rosji specyficzną pozycję. W carskiej Rosji była obszarem o największej powierzchni, jednak słabo zaludnionym i bardzo słabo poznanym. Zły stan wewnętrznej komunikacji powodował utrudnioną łączność ze stolicą i poszczególnymi regionami Rosji. Syberia znajdowała się w pozycji ekonomicznej kolonii, surowcowego zaplecza Rosji, którą carska władza wykorzystywała jako miejsce politycznego i karnego zesłania ${ }^{1}$.

Syberia miała jednak opinię regionu o skłonnościach do separatyzmu. Sprzyjało temu jej geograficzne położenie, a także swoistość ekonomicznego rozwoju i sposób administrowania obszarem. Wszystkie te czynniki tworzyły dogodne warunki do wykrystalizowania się wśród tamtejszej inteligencji miejskiej „specyficznych” nastrojów, które w XIX wieku przyczyniły się do powstania syberyjskiego regionalnego ruchu („obłastniczestwo”).

Syberyjski regionalny ruch powstał w XIX wieku, a jego podstawy tworzyła idea o swoistości Syberii. Zwolennicy ruchu twierdzili, że Syberia jest wyjątkowym obszarem, niepodobnym do Rosji i z tego właśnie powodu ma prawo do swojej osobnej egzystencji i rozwoju w ramach rosyjskiego imperium albo poza nim. Reprezentantem syberyjskiego regionalnego ruchu na początku jego istnienia stało się petersburskie Syberyjskie Koło. Jego działalność wiązała się z nazwiskami syberyjskich rodaków: G. N. Potanina ${ }^{2}$ oraz N. M. Jadrincewa ${ }^{3}$, którzy stopniowo stawali się głównymi jego protagonistami. Idee syberyjskiego regionalnego ruchu nie znajdowały jednak wśród obywateli Syberii i miejscowej inteligencji wielkiego poparcia.

Początek XX wieku przyniósł ożywienie regionalnego ruchu na Syberii. Na zebraniu jego członków i sympatyków, które odbyło się 12 stycznia 1905 roku w Tomsku, z udziałem syberyjskiej inteligencji otwarcie mówiono o potrzebie wprowadzenia na Syberii samorządów. Zajmowano się także innymi palącymi syberyjskimi problemami. Syberyjscy regionaliści (termin ten traktujemy jako odpowiednik rosyjskiej nazwy „obłastnici”) uważali, że ogólna sytuacja polityczna w Rosji w roku 1905 jest na tyle przyjazna, iż zaczęli rozmyślać o założeniu organizacji, która legalnie chroniłaby polityczne interesy Syberii. W dniach 28-29 sierpnia 1905 roku odbył się w Tomsku pierwszy zjazd syberyjskich regionalistów. Na zjeździe tym utworzono Syberyjski Regionalny Związek, którego prze-

${ }^{1}$ В. И. Шишкин, Москва - Сибирь. История взаимоотношений (1917-1933). История Сибири: человек, общество, государство, Новосимбирск 1995, с. 43.

${ }^{2}$ G. N. Potanin (1835-1920) był etnografem i folklorystą, który poświęcił swoje życie badaniu Syberii i Środkowej Azji. W latach 1859-1861 studiował na Uniwersytecie Petersburskim, gdzie zaangażował się w polityczną działalność, za co został uwięziony i w roku 1861 zesłany na Syberię. Uwolniony został w roku 1874. Uczestniczył w kilku wyjazdach badawczych po Syberii i Środkowej Azji. Wyniki swoich badań publikował w fachowych pracach, które wniosły wkład w poznanie życia rdzennych mieszkańców Syberii.

${ }^{3}$ N. M. Jadrincew (1842-1894) był archeologiem i etnografem. W roku 1865 został uwięziony za agitowanie na rzecz autonomii Syberii. W więzieniu i na wygnaniu spędził 9 lat. Wkrótce stał się aktywnym przedstawicielem syberyjskiego regionalnego ruchu. W roku 1882 założył czasopismo „Wostocznoje obozrienije”, w którym krytykował politykę władzy wobec Syberii. 
wodniczącym został G. Potanin. Zjazd przyjął dokument, w którym stwierdzono, że Syberia jest nieodłączną częścią Rosji, ale współcześnie ze względu na swoje historyczne, geograficzne, etnograficzne i społeczno-ekonomiczne właściwości stanowi samodzielny region, potrzebujący własnego samorządu. Tym regionalnym samorządem miała być Syberyjska Regionalna Duma, do której zadań należałoby samodzielne rozwiązywanie wszystkich problemów związanych z kulturalnym, ekonomicznym i socjalnym życiem na Syberii ${ }^{4}$.

Mimo starań i ambicji głównych przywódców syberyjskich regionalistów, na początku XX wieku ruch nie stał się jednoczącą siłą społecznego i politycznego życia na Syberii. Na początku swojego istnienia syberyjski ruch regionalny nie wychodził w podstawowych postulatach poza ogólne prawa obywatelskie. W latach 1905-1907 po raz pierwszy żądania ruchu przybrały postać politycznego programu i chociaż po roku 1907 idee regionalnego ruchu i postulaty syberyjskiej autonomii były żywe w regionie, to na ich realizację Sybiracy i członkowie ruchu musieli czekać do roku 1917.

Lutowe wydarzenia roku 1917 i powstanie Tymczasowego Rządu znalazły oddźwięk także na Syberii. Zwolennicy syberyjskiego regionalnego ruchu przyjęli upadek caratu jako okoliczność, która

otworzy przed Syberią ogromne możliwości społecznego i gospodarczego rozwoju. Syberia przestanie być pańszczyźniana, a stanie się z niej wolny region nie tylko w gospodarczo-ekonomicznym rozwoju, ale też społeczno-politycznych założeniach ${ }^{5}$.

Wydarzenia rozgrywające się w europejskiej części Rosji były sygnałem do zwiększenia starań i aktywności syberyjskich regionalistów, którzy w tym czasie stali się głównymi popularyzatorami idei syberyjskiej autonomii. Na wiosnę i w lecie 1917 roku różne grupy regionalistów wezwały obywateli Syberii, aby przyjęli rozporządzenia konieczne do wprowadzenia autonomii i zapewnienia równorzędnej pozycji Syberii wewnątrz federalnego państwa.

Dnia 10 maja 1917 roku w Tomsku odbyło się pod kierownictwem G. N. Potanina Narodowe Zgromadzenie całej guberni, na którym rokowano o autonomii Syberii. Wtedy regionaliści po raz pierwszy wyszli na ulice z biało-zielonymi flagami autonomicznej Syberii. Podobne zgromadzenia odbywały się także w innych syberyjskich miastach. W uchwale przyjętej na tym zgromadzeniu stwierdzano:

Syberia do tego, aby przerwała organiczny związek z Rosją, musi mieć swoją Syberyjską Dumę Obwodową, która będzie wydawać ustawy/stanowić prawa ukierunkowane na wewnętrzne życie na Syberii. W ogólnych państwowych problemach Syberia będzie podporządkowywać się wszechrosyjskim prawom ${ }^{6}$.

Polityczna atmosfera, która panowała w tym czasie w syberyjskich miastach, umożliwiła regionalistom postawienie pytania o autonomię Syberii i szansę doprowadzenia do pierwszego regionalnego zjazdu syberyjskiego. Wcześniej jednak, zanim doszło do jego

${ }^{4}$ С. Г. Сватиков, Россия и Сибирь. (К истории сибирского областничества в 19. веке), Прага 1929, c. $114-116$.

${ }^{5}$ Вольная Сибирь, Прага 1927, н. 2, с. 4-5.

${ }^{6}$ Вольная Сибирь, Прага 1927, н. 2, с. 20. 
zwołania, regionaliści potrzebowali wzmocnienia swojej pozycji na politycznej scenie i zyskania dla swojego programu również pozostałych politycznych podmiotów.

Najbliższa regionalistom była partia eserowców, w której widzieli wpływową siłę polityczną z szeroką bazą socjalną. Pewne podobieństwa znajdowali także w swoich programach, gdyż w programie eserowców znalazła się, między innymi, kwestia federacji i regionalnej autonomii. Regionaliści mogli w dodatku liczyć na poparcie narodowych socjalistów i częściowo mienszewików. Z kolei bolszewicy do idei regionalnego ruchu odnosili się negatywnie. Najważniejszymi zadaniami syberyjskich regionalistów w roku 1917 stało się przygotowanie wyborów do Wszechrosyjskiego Zgromadzenia Ustawodawczego, propagowanie celów regionalnego ruchu, zaś przede wszystkim syberyjskiej autonomii i zorganizowanie ogólnosyberyjskiego zjazdu regionalnego.

Obrady Syberyjskiego Regionalnego Zjazdu rozpoczęły się 2 sierpnia 1917 roku w Tomsku. Ze względu na sytuację w kraju i lipcowe zwiększenie aktywności przez bolszewików na zjazd przybyło tylko 64 delegatów, wobec czego uczestnicy zdecydowali, że będą go uważać jedynie za rodzaj konferencji, której misją będzie przygotowanie materiałów na zjazd właściwy. O atmosferze, która panowała na wspomnianej konferencji, świadczy fakt, że obrady przebiegały pod hasłem Niech żyje autonomiczna Syberia, a delegaci zawiesili biało-zieloną syberyjską flagę ${ }^{7}$.

Następnego dnia na konferencji przyjęto uchwałę O autonomicznym ustroju Syberii, która zawierała przyjęte przez uczestników najistotniejsze postanowienia dotyczące autonomii Syberii. Podkreślono jednak, że to stanowisko jest postulatem, który można wykorzystać zarówno w przygotowaniach do powołania Zgromadzenia Ustawodawczego, jak i w proponowanym projekcie autonomii rosyjskich regionów. Delegaci ustalili, że najpóźniej 15 października 1917 roku zostanie zwołany zjazd przedstawicieli guberni i regionów Syberii, na którym ponownie będzie się dyskutować o problemach syberyjskiej autonomii.

Pierwszy Syberyjski Regionalny Zjazd odbył się w planowanym terminie - 8 października 1917 roku w auli Uniwersytetu Syberyjskiego w Tomsku. Na zjazd przybyło 169 delegatów, którzy reprezentowali 171 społecznych, politycznych, narodowościowych i innych organizacji działających na Syberii ${ }^{8}$. Głównym punktem programu było zagadnienie stworzenia autonomicznego systemu na Syberii. Z przedstawionych przez M. B. Szatiłowa i E. W. Zacharowa referatów wstępnych, wyjaśniających zasady syberyjskiej autonomii, wynikało, że Syberia musi mieć pełną władzę ustawodawczą, wykonawczą i sądowniczą. Władzę ustawodawczą miała sprawować Syberyjska Obwodowa Duma, zaś władzę wykonawczą - rząd syberyjski, odpowiedzialny przed syberyjskim parlamentem. Działanie władzy sądowniczej na Syberii miał gwarantować powołany Sądowy Senat. Niektórzy eserowcy - regionaliści proponowali też stworzenie własnych sił zbrojnych i wprowadzenie syberyjskiego obywatelstwa9 .

15 października 1917 roku zjazd wybrał Komitet Wykonawczy pierwszego Syberyjskiego Zjazdu Obwodowego ${ }^{10}$ i przyjął uchwałę $O$ autonomii Syberii, w której określono autonomiczny system Syberii i jego prawomocność. Uregulowano też stosunek do Repub-

\footnotetext{
${ }^{7}$ Вольная Сибирь, Прага 1927, н. 2, с. 23.

${ }^{8}$ Вольная Сибирь, Прага 1927, н. 2, с. 29.

${ }_{9}^{9}$ Тимонина, Н.: Сибирьское областничество (60-е гг. X IX в. - 1920 г., Глубинка, 1995, н. 1, с. 23.

${ }^{10}$ Członkami Komitetu zostali: G. N. Potanin (przewodniczący), W. M. Krutowskij, B. M. Gan, M. B. Szatiłow, E. W. Zacharow, N. A. Aleksiejew, A. A. Jermiekow, S. A. Nowgorodow.
} 
liki Rosyjskiej, nie wykluczając możliwości przekształcenia Syberii w federację, jeśli syberyjskie narody i narodowości będą tego oczekiwać ${ }^{11}$.

Październikowe wydarzenia 1917 roku w Petersburgu spotkały się z odzewem na Syberii. W Omsku, Irkucku i Nowonikołajewsku odbyły się protestacyjne zgromadzenia. Syberyjskie organizacje społeczne jednomyślnie potępiły przewrót bolszewicki. W takiej sytuacji Syberyjski Komitet Wykonawczy, wybrany na pierwszym Wszechrosyjskim Zjeździe Obwodowym, zdecydował się w przyspieszonym tempie zwołać nadzwyczajny Wszechrosyjskiego Zjazd Obwodowy, na którym cała demokratyczna Syberia wypowiedziałaby się na temat przejęcia władzy przez bolszewików i poszukała sposobu zorganizowania własnej regionalnej władzy.

W Nadzwyczajnym Wszechrosyjskim Zjeździe Obwodowym, który odbył się 6 grudnia 1917 roku w Tomsku, uczestniczyło 155 delegatów. Zjazd przebiegał w napiętej sytuacji politycznej. Ponieważ głównym punktem programu było utworzenie administracji autonomicznej Syberii, przyjęto uchwałę o powołaniu tymczasowych organów administracyjnych, którymi miały stać się Syberyjska Duma Obwodowa i Syberyjska Rada Obwodowa ${ }^{12}$.

Zjazd zakończył się 15 grudnia 1917 roku wyborem Tymczasowej Syberyjskiej Rady Obwodowej, której zadaniem było zwołanie Syberyjskiej Dumy Obwodowej i przygotowanie wyborów do Wszechrosyjskiego Zgromadzenia Ustawodawczego ${ }^{13}$.

Pierwszym krokiem nowo wybranej rady, na czele z jej przewodniczącym G. N. Potaninem, była deklaracja nieuznająca bolszewickiej władzy i jej dekretów przez Syberyjską Radę Obwodową oraz proklamowanie na Syberii władzy autonomicznej. Wezwano też obywateli Syberii do utworzenia rewolucyjnego demokratycznego frontu. Tymczasowa Syberyjska Rada Obwodowa w rzeczywistości stała się pierwszą regionalną władzą Syberii.

Na siedzibę Syberyjskiej Rady Obwodowej powołano Tomsk, a jej pierwsze posiedzenie odbyło się 16 grudnia 1917 roku. Za główny punkt programu uznano zwołanie Syberyjskiej Dumy Obwodowej, której obrady miały się rozpocząć 7 stycznia 1918 roku. Rada wydała odezwę do obywateli Syberii, w której pisano: „najważniejszym zadaniem Syberyjskiej Rady Obwodowej jest zwołanie Tymczasowej Syberyjskiej Dumy Obwodowej" 14 . Wspomniana odezwa miała Sybirakom przybliżyć nie tylko cele Rady, ale też przebudzić w nich lokalny patriotyzm i sprawić, że poprą ideę syberyjskiej autonomii.

Ponadto Syberyjska Rada Obwodowa zaczęła wysyłać swoich politycznych emisariuszy do wszystkich większych i mniejszych syberyjskich miast, co uzasadniano następująco:

jest konieczne organizowanie syberyjskiego społeczeństwa, zapoznawanie go z aktywną pracą regionalistów, pokazywanie mu sposobów wykorzystania twórczych sił w walce o autonomię Syberii ${ }^{15}$.

${ }^{11}$ Культурно-национальная автономия в истории России. Документальная антология. Т. I, Сибирь 1917-1920, Томск 1998, с. 66.

${ }^{12}$ Культурно-национальная автономия в истории России. Документальная антология. Т. I, Сибирь 1917-1920, Томск 1998, с. 73-78.

${ }^{13}$ Członkami Syberyjskiej Rady Obwodowej zostali: G. N. Potanin (przewodniczący), P. J. Derber, A. E. Nowosielow, G. B. Patuszinskij, M. B. Szatiłow, A. A. Jermiekow, E. W. Zacharow.

${ }^{14}$ Вольная Сибирь, Прага 1928, н. 3, с. 11.

${ }^{15}$ Вольная Сибирь, Прага 1928, н. 3, с. 14. 
Niestety, starania syberyjskich regionalistów i Syberyjskiej Rady Obwodowej o powołanie Syberyjskiej Dumy Obwodowej, która mogłaby być alternatywną wobec bolszewików władzą na Syberii, nie znalazły pożądanego oddźwięku wśród syberyjskiego społeczeństwa. Wprost przeciwnie, działania regionalistów, i to z niepokojem, obserwowali przede wszystkim bolszewicy.

W połowie grudnia 1917 roku stosunki polityczne na Syberii stawały się coraz bardziej skomplikowane, a pozycja Syberyjskiej Rady Obwodowej, która musiała stawić czoła nie tylko naciskowi bolszewików, ale też nieprzyjaznemu stanowisku partii kadetów oraz syberyjskich przedstawicieli handlowych i przemysłowych, coraz bardziej niepewna. Sytuacja zaostrzyła się także w samej radzie (polaryzacja politycznych postaw poszczególnych członków, brak jednomyślnych ustaleń odnośnie do dalszego postępowania i temu podobne), co doprowadziło do rezygnacji G. N. Potanina ze stanowiska jej przewodniczącego. Na początku stycznia 1918 roku w Tomsku rozpowszechniono informację, że bolszewicy rozgonili Wszechrosyjskie Zgromadzenie Ustawodawcze ${ }^{16}$. Oceniając sytuację w regionie, Syberyjska Rada Obwodowa uznała, że jedynym wyjściem jest oddanie przez bolszewików w centrum władzy w ręce Wszechrosyjskiego Zgromadzenia Ustawodawczego, a na Syberii w ręce Syberyjskiej Dumy Obwodowej. Rada zwróciła się do wszystkich Sybiraków z wezwaniem do zjednoczenia się wokół Syberyjskiej Dumy Obwodowej, której posiedzenie miało się zacząć 7 stycznia 1918 roku. Jednocześnie członkowie syberyjskiej rady wysłali telegram do Rady Komisarzy Ludowych w Petersburgu, w którym żądali, aby przekazali władzę Wszechrosyjskiemu Zgromadzeniu Ustawodawczemu. W telegramie pisano m.in.:

Uzurpowanie władzy należącej do Wszechrosyjskiego Zgromadzenia Ustawodawczego przez Radę Komisarzy Ludowych doprowadzi do skrajnego zaostrzenia stosunków Syberii z Petersburgiem. Władzy uzurpatorów Syberia nie uznaje ${ }^{17}$.

W tak napiętej sytuacji politycznej w styczniu 1918 roku Syberyjska Rada Obwodowa zwołała pierwsze posiedzenie Syberyjskiej Dumy Obwodowej. Członkowie Syberyjskiej Dumy Obwodowej spotkali się co prawda w Tomsku, ale bolszewicy rozpędzili to pierwsze posiedzenie dumy ${ }^{18}$. Niemniej sowiecka władza utrzymała się w zachodniej Syberii tylko do lata 1918 roku, kiedy musiała ustąpić przed naciskiem sił białogwardzistów.

$\mathrm{Na}$ wiosnę 1918 roku, kiedy bolszewicy pozbawili syberyjskie regionalne organy władzy i na parę miesięcy przejęli rządy na Syberii, do rozwoju wydarzeń w Zachodniej Syberii włączył się też Legion Czechosłowacki. Na podstawie umowy z bolszewikami z 26 marca 1918 roku legioniści mieli wędrować w kierunku na wschód, aż do Władywostoku, skąd planowano ich przesunąć na europejskie pola walki. Legion Czechosłowacki, zgodnie z umową, miał przemieszczać się nie jako wojskowe zgrupowanie, ale jako ,grupa obywateli posiadająca broń, aby mogła się bronić przed napaścią kontrrewolucjonistów"19.

\footnotetext{
${ }^{16}$ Porównaj nр.: В. В. Журавлев, Н. С. Симонов, Причины и последствия разгрома Учредительного собрания, [в:] Вопросы истории, 1992, н. 1, с. 3-18; Всероссийское Учредительное собрание и демократическая альтернатива. Два взгляда на проблемы, [в:] Отечественная история, 1993, н. 5, с. 3-39.

${ }^{17}$ Н. Тимонина, Сибирьское областничество (60-е гz. ХІХ в.-1920 г.), [в:] Глубинка, 1995, н. 1, с. 21.

${ }^{18}$ Więcej o rozwoju w roku 1918 zobacz na przykład: L. Harbul'ová, Sibirsky autonomizmus. Zdroje, prejavy, reflexie (1917-1939), Praha 2010.

${ }^{19}$ K. Pichlík, B. Klípa, J. Zabloudilová, Českoslovenští legionáři (1914-1920), Praha 1996, s. 85-119.
} 
Przemieszczenie tak liczebnego i uzbrojonego wojskowego zgrupowania przez krainę, w której toczyła się wojna domowa, nie było łatwe. Realizacja umowy była utrudniona, gdyż miejscowa sowiecka władza chciała Legion rozbroić. Sytuacja stawała się coraz bardziej burzliwa. W maju 1918 roku w Czelabińsku przerodziła się w otwarty konflikt, w wyniku którego czechosłowackie jednostki przeszły do otwartych działań wojennych i zaczęły zajmować tereny wzdłuż Kolei Transsyberyjskiej, aby otworzyć sobie drogę do Władywostoku. Wystapienie Legionu Czechosłowackiego zaktywizowało rosyjskie antybolszewickie siły polityczne. Stopniowo zaczął się tworzyć związek między dowództwem czechosłowackich jednostek a formującymi się wojskowymi jednostkami antybolszewickimi w zachodniej Syberii. Pułkownik Aleksiej N. Griszin-Ałmazow, dowódca zachodniosyberyjskiego wojskowego okręgu Tymczasowego Syberyjskiego Rządu, 19 czerwca 1919 poinformował rząd, że wspólnie z czechosłowackim wojskiem przystępuje do działania przeciw bolszewickim formacjom na Syberii:

Zdecydowałem się poprzeć zaczynający się ruch Czechosłowaków moimi jednostkami w celu oczyszczenia zachodu Syberii z bolszewików. Wojska Tymczasowego Syberyjskiego Rządu razem z Czechosłowakami kontrolują dużą przestrzeń i kolej ${ }^{20}$.

Syberyjski rząd, zdając sobie sprawę ze znaczenia czechosłowackich jednostek, wydał oświadczenie, w którym docenił nie tylko sukcesy Legionu Czechosłowackiego w walkach o Syberię, ale podkreślił też możliwość współpracy w dążeniu do osiągnięcia wspólnych celów ${ }^{21}$.

W konsekwencji 23 lipca 1918 roku między Ministerstwem Spraw Zagranicznych Tymczasowego Rządu Autonomicznej Syberii a przedstawicielem Czechosłowackiej Rady Narodowej w Rosji (dalej CSNR), dr. Václavem Girsą, odbyły się rokowania, których celem było omówienie możliwości bliższych kontaktów między CSNR a Tymczasowym Rządem Syberii. Przedstawiciel CSNR gwarantował syberyjskiemu rządowi uczciwe podejście ze strony czechosłowackich jednostek. Kilka dni później, 29 lipca 1918 roku miały miejsce dalsze rozmowy Arkadija A. Krakowieckiego, głównego dowódcy Syberyjskiej Armii, z przedstawicielami czechosłowackich jednostek wojskowych. Głównym punktem spotkania były organizacja i zaopatrzenie Syberyjskiej Armii, a także rozwój sił wojskowych i zasady tworzenia armii. Jednocześnie rokowano o utworzeniu syberyjskiego oddziału rosyjskiego, który planowano przyłączyć do czechosłowackich jednostek w celu wyszkolenia ${ }^{22}$.

Przywódcy Legionu Czechosłowackiego trzymali się jednak zarządzenia T. G. Masaryka, ówczesnego przewodniczącego CSNR, który w lipcu 1918 roku w telegramie do czechosłowackiego wojska w Rosji pisał: „Będziemy lojalni i nie będziemy bez potrzeby wtrącać się do wewnętrznych zależności" ${ }^{23}$.

Po upadku bolszewickiego rządu w czerwcu 1918 roku na Syberii na nowo podjęły działalność syberyjskie organy autonomiczne. W lecie 1918 roku w Tomsku wznowiła

${ }^{20}$ Dokumenty a materiály k dějinám československo-sovětských vztahu. Díl I. (november 1917-august 1922). Praha Academia 1975, (d’alej len DMČSSV), s. 135.

${ }^{21}$ Государственный архив Российской федерации (дальше ГАРФ) Moskva. ф. 185, оп, 1. д. $2 .$, л. 9.

${ }^{22}$ ГАРФ. ф. 175, оп. 1. д. 14.

${ }^{23}$ DMČSSV. D. I., s. 164. 
pracę Syberyjska Duma Obwodowa, a w Omsku został powołany nowy Syberyjski Rząd Tymczasowy pod przewodnictwem Piotra Wołogodskiego ${ }^{24}$. Wzajemne relacje obu organów i ich działalność stały się w rezultacie decydującym czynnikiem destabilizującym wewnętrzną syberyjską scenę polityczną i antybolszewicką opozycję, co było spowodowane odmiennym składem politycznym wspomnianych autonomicznych organów oraz animozjami ich głównych przedstawicieli. Ten stan w pełni ujawnił się w sierpniu 1918 roku, kiedy Syberyjski Rząd Tymczasowy coraz bardziej ulegał wpływom liberalno-monarchistycznych kręgów, z kolei w Syberyjskiej Dumie Obwodowej nadal dominowali eserowcy. W działaniach Syberyjskiego Rządu Tymczasowego coraz wyraźniej przejawiały się autorytarne postawy, wzrastała biurokracja i centralizm. Punktem kulminacyjnym było powołanie w sierpniu 1918 roku Rady Administracyjnej, za pośrednictwem której Syberyjski Rząd Tymczasowy zmienił się w autorytarny organ władzy.

Przywódcy Legionu Czechosłowackiego nawiązali kontakty z Syberyjskim Rządem Tymczasowym, główną polityczną siłą, zaraz gdy tylko się ukonstytuował. Po początkowych planach współpracy w dziedzinie wojskowej i entuzjazmie obywateli, którzy witali Czechosłowaków jako wyzwolicieli od bolszewickiej władzy, pojawiły się i w Legionie, i w Syberyjskim Rządzie Tymczasowym pierwsze problemy. Przewodniczący Syberyjskiego Rządu Tymczasowego P. Wołogodski rozmawiał wprawdzie regularnie z czechosłowackimi przywódcami, na przykład z dr. Girsą albo z majorem Košekiem, uczestniczył w akcjach, które organizowali legioniści (koncerty, uroczyste zgromadzenia, oficjalne posiedzenia), ale jednocześnie docierały do niego coraz częściej informacje o narastającym napięciu między dowódcami syberyjskiego wojska i przedstawicielami miejscowego samorządu a żołnierzami Legionu Czechosłowackiego. Na przykład pułkownik Griszin-Ałmazow w swoim emocjonalnym wystąpieniu w Czelabińsku powiedział, że ,rosyjska armia nie potrzebuje sojuszników, a już w ogóle nie Czechosłowaków” ${ }^{25}$. Komisarz z Krasnojarska w sierpniu 1918 roku poinformował P. Wołogodskiego, że „czeski sąd polowy skazał na karę śmierci rosyjskiego obywatela za naklejanie socjalistycznych proklamacji i wyrok został wykonany" ${ }^{26}$. P. Wołogodski, który uznał takie postępowanie za niedopuszczalne, stwierdził, że należy „znaleźć sposób, aby uniemożliwić Czechom taką samowolę27.

Przedstawione wydarzenia w pewnym stopniu odzwierciedlały także narastające wewnętrzne napięcie polityczne na Syberii, do którego dochodziło z powodu rozdźwięku między Syberyjskim Rządem Tymczasowym a Syberyjską Dumą Obwodową. Napięcie to osiagnęło punkt kulminacyjny w październiku 1918 roku. Przywódcy Legionu Czechosłowackiego pod względem politycznym byli bliżej Syberyjskiej Dumy Obwodowej i jej reprezentantów (przede wszystkim jej przewodniczącego Iwana Jakuszewa), co zostało potwierdzone przez ich stosunek do wydarzeń, które miały miejsce w najbliższych miesiącach.

Najistotniejszym problemem, wpływającym negatywnie na rozwój całego antybolszewickiego ruchu na terytorium Rosji, była niejednomyślność poglądów reprezentowanych przez przywódców białogwardzistów. Niekorzystne było też powstawanie różnych regionalnych rządów i centrów oporu, których działania, niestety, nie były skoordynowane.

${ }^{24}$ Piotr Wasiliewicz Wołogodski (1863-1928, Szanghaj), prawnik. W roku 1918 przewodniczący Tymczasowego Syberyjskiego Rządu. Członek władzy admirała Kołczaka. Po upadku Kołczaka emigrował do Chin.

25 За спиной Колчака. Документы и материаль. Под редакцией А. В. Квакина, Москва 2005, с. 81.

26 За спиной Колчака. Документы и материаль, с. 87.

27 За спиной Колчака. Документы и материаль, с. 87. 
Starając się sprostać naciskowi światowych mocarstw, ale także uwzględniając wyniki własnych analiz sytuacji w Rosji, Syberyjski Rząd Tymczasowy pod przewodnictwem Piotra Wołogodskiego 4 września 1918 roku zwrócił się do wszystkich miejscowych władz $\mathrm{z}$ apelem o utworzenie jednej rosyjskiej władzy.

Wspólne rokowania reprezentantów głównych centrów antybolszewickiego oporu w Rosji odbyły się w Ufie w dniach od 8 do 23 września 1918 roku i przebiegały w napiętej atmosferze. W wyniku przeprowadzonych rozmów powołano Ogólnorosyjski Rząd Tymczasowy, na którego czele stał Dyrektoriat złożony z pięciu członków (N. D. Awksientjew, W. M. Zienzinow, P. W. Wołogodski, W. A. Winogradow, generał W. Bołdyriew). Siedzibą Dyrektoriatu został Omsk, gdzie miał także swoją siedzibę Syberyjski Rząd Tymczasowy ${ }^{28}$.

Na podstawie umów ufijskich Syberyjski Rząd Tymczasowy miał przekazać władzę w ręce Ogólnorosyjskiego Rządu Tymczasowego, natomiast Syberyjska Duma Obwodowa miała zostać rozwiązana. Niemniej przeciwko likwidacji Dumy wystapili nie tylko jej członkowie, ale także przedstawiciele Ententy i Legionu Czechosłowackiego. Jako argument przywoływano fakt, że zwołanie Syberyjskiej Dumy Odwodowej uspokoi demokratyczną opinię publiczną w Europie i w USA. O utrzymanie Syberyjskiej Regionalnej Dumy aktywnie starali się przedstawiciele legionistów. W związku z tym 14 października 1918 roku członek Czechosłowackiej Rady Narodowej w Rosji, F. Richter, odwiedził P. Wołogodskiego. Podczas rozmowy powiedział, że „rozwiązanie Syberyjskiej Dumy Obwodowej będzie dla CSNR dowodem na to, aby Legion odszedł z Syberii" ${ }^{29}$. Przedstawiciele Ententy i Legionu Czechosłowackiego spotkali się z P. Wołogodskim 17 października 1918 roku, aby znaleźć kompromis w rokowaniach i doprowadzić do połączenia Ogólnorosyjskiego Rządu Tymczasowego i Syberyjskiego Rządu Tymczasowego. Miało to ustabilizować sytuację na Syberii i w całej Rosji ${ }^{30}$.

Przekazanie władzy Ogólnorosyjskiemu Rządowi Tymczasowemu przez Syberyjski Rząd Tymczasowy odbyło się 3 listopada 1918 roku. Niestety, mimo interwencji przedstawicieli mocarstw i czechosłowackich legionistów, 10 listopada 1918 roku podjęto decyzję o rozwiązaniu Syberyjskiej Dumy Obwodowej, co w rezultacie osłabiło także pozycję Ogólnorosyjskiego Rządu Tymczasowego.

Utworzenie Ogólnorosyjskiego Rządu Tymczasowego - Dyrektoriatu było wynikiem kompromisu osiągniętego podczas rokowań w Ufie, który de facto zadecydował o długości jego istnienia. Polityczne zróżnicowanie Dyrektoriatu (eserowcy, kadet, bezpartyjni) ujawniło się już w pierwszych dniach jego działalności, a spotęgowało, gdy bolszewicy przeszli do ataku i ponownie zajęli Samarę. Seria niepowodzeń i porażek na froncie oraz polityka eserowców na zapleczu doprowadziły do konsolidacji prawicowej części syberyjskiego politycznego spektrum i jednostek wojskowych. Sytuacja w Omsku zaostrzyła się w nocy z 17 na 18 listopada 1918 roku, kiedy zostali aresztowani członkowie Dyrektoriatu, a władza przeszła w ręce Gabinetu Ministrów, którzy wybrali admirała A. W. Kołczaka na swojego „naczelnego władcę”. Mianowanie admirała A. W. Kołczaka „naczelnym

\footnotetext{
${ }^{28}$ Nowo utworzony Tymczasowy Ogólnorosyjski Rząd nie miał jednak siedziby ani własnego aparatu administracyjnego, dlatego zdecydował się wykorzystywać siedzibę i aparat Tymczasowego Syberyjskiego Rządu.

29 За спиной Колчака. Документы и материаль, с. 123.

30 За спиной Колчака. Документь и материаль, с. 124.
} 
władcą Rosji” sprawiło, że rozwój wydarzeń na Syberii stracił definitywnie niezależny syberyjski wymiar i nabrał wszechrosyjskiego charakteru.

Przejęcie władzy przez admirała Kołczaka nie zostało jednak przyjęte jednoznacznie ani na Syberii, ani w całej niebolszewickiej Rosji ${ }^{31}$. Fakt ten nie został zaakceptowany nie tylko przez część rodzimej politycznej reprezentacji, ale też przez żołnierzy Legionu Czechosłowackiego. Dnia 21 listopada 1918 roku przedstawiciele Czechosłowackiej Rady Narodowej w Rosji i wojskowe dowództwo Legionu wydali oświadczenie, w którym napisali:

Czechosłowacka armia walcząca za ideały wolności i narodowej suwerenności nie może i nie będzie popierać przewrotu w Omsku z 18 listopada, który pozostaje w niezgodzie z tymi ideałami ${ }^{32}$.

Oświadczenie to 22 listopada 1918 roku zostało zamieszczone w jekaterynburskiej prasie i wywołało burzliwe reakcje. Zostało również uznane za ingerencję w wewnętrzne rosyjskie sprawy. Jeden z dzienników w Czelabińsku napisał: „Bracia są wprawdzie braćmi, dziękujemy im za pomoc na froncie, ale prosimy nie interweniować w nasze życie"33.

Oświadczenie przedstawicieli zarówno CSNR w Rosji, jak i Legionu wywołało nie tylko emocjonalne reakcje w prasie, ale też niezadowolenie omskiego rządu Kołczaka. Jego reprezentanci uświadomili sobie wagę postawy, jaką zajęło czechosłowackie wojsko przede wszystkim z tego powodu, że Legion ciągle pozostawał realną siłą wojskową. Chociaż legioniści poparli Syberyjski Rząd Tymczasowy Wołogodskiego, a z przedstawicielami Syberyjskiej Dumy Obwodowej utrzymywali ożywione kontakty, to jednak z rządem admirała Kołczaka trudno znajdowali porozumienie.

Pod koniec 1918 roku czechosłowackie wojsko na Syberii znalazło się w trudnej sytuacji, którą jeszcze bardziej komplikowało wzrastające wewnętrzne napięcie wśród żołnierzy Legionu. W tak złożonej sytuacji na Syberię przybył generał Milan Rastislav Štefánik. Štefánik już podczas podróży do zachodniosyberyjskich miast, w których byli dyslokowani czechosłowaccy żołnierze, otrzymywał informacje o napiętych stosunkach między Legionem a rządem Kołczaka, który coraz częściej winił przywódców czechosłowackiego wojska za udzielanie pomocy eserowcom i sympatie dla nich. Mimo tych skomplikowanych stosunków, Kołczak dążył do tego, aby przyłączyć czechosłowackie wojsko do rosyjskiego i ponownie włączyć je do walki z bolszewikami pod rosyjskim dowództwem. W dniach 19-20 grudnia 1918 roku w Omsku Štefánik i generał Janin spotkali się z Kołczakiem. Głównym punktem rozmów był problem dowodzenia wojskiem. Admirał Kołczak starał się, żeby dowództwo wszystkich wojsk znajdujących się na terytorium Syberii podlegało rosyjskiej stronie, ale ponieważ ani Štefánik, ani Janin nie zgodzili się na to, rozmowy zakończyły się niepowodzeniem ${ }^{34}$.

\footnotetext{
31 За спиной Колчака. Документы и материаль, с. 308.

${ }^{32}$ Георгий Константинович Гинс, Сибирь, союзники и Колчак. Поворотный момент русской истории 1918-1920, впечатления и мысли члена Омского правительства, Москва 2007, с. 256.

${ }^{33}$ Георгий Константинович Гинс, Сибирь, союзники и Колчак. Поворотньй момент русской истории 1918 - 1920, впечатления и мысли члена Омского правительства, с. 256.

${ }^{34}$ Евгений Фирсов, Милан Растислав Штефаник в России. (По опертивным материалам ияарской и колчаковской власти, Милан Растислав Штефаник. Новый взгляд, Мартин 2001, с. 47.
} 
Idea wykorzystania Legionu Czechosłowackiego do wsparcia walki przeciw bolszewikom pojawiła się także podczas obrad Konferencji Pokojowej w Paryżu. Jej inicjatorzy liczyli na aktywniejsze poparcie czechosłowackich jednostek podczas ofensywy Kołczaka, której szczyt przypadał na wiosnę 1919 roku. Rząd Kołczaka doceniając to, co zrobili Czesi i Słowacy dla Rosji na Syberii, wydał decyzję, na podstawie której czechosłowaccy obywatele walczący przeciw bolszewikom mogli nabywać majątki na Syberii ${ }^{35}$. Z drugiej strony Kołczak uświadamiał sobie podejście Czechów i Słowaków do swojej władzy i wiedział o ich negatywnym stosunku do dalszego udziału w walce. W tym czasie legioniści myśleli już tylko o powrocie do domu, a uczestniczenie w rozwiązywaniu rosyjskich problemów nie mogło ich zmusić do walki w Rosji.

W tej sytuacji niektórzy polityczni przywódcy białogwardzistów zaproponowali, aby pozyskać z szeregów Legionu Czechosłowackiego ochotników, którzy spróbowaliby przedrzeć się do Denikina, połączyć się z nim i dostać do domu tą krótszą drogą ${ }^{36}$. Ich wysłannicy rokowali z politycznym i wojskowym dowództwem czechosłowackich jednostek we wrześniu 1919 roku, jednak generał Janin stwierdził, że bez zgody czechosłowackiego rządu nie pozwoli na taki nabór w wojsku. Stanowisko rządu, wojskowego dowództwa i samych legionistów było jednoznaczne - należy wrócić do domu.

Przedstawiciele syberyjskiego rządu zintensyfikowali swoje starania, aby utrzymać czechosłowackie wojska na stronie białogwardzistów głównie po tym, kiedy na froncie zaczął się odwrót wojsk Kołczaka. Dnia 11 października 1919 roku przewodniczący Rady Ministrów Syberyjskiego Rządu Tymczasowego P. Wołogodski zwrócił się do pełnomocnika czechosłowackiego rządu w Rosji Bohdana Pavlu z propozycją zawarcia umowy, która rozwiązywałaby problemy politycznych i ekonomicznych stosunków między Rosją a Czechosłowacją. Propozycja zawierała też konkretne propozycje. Strona rosyjska zakładała, że

dalsza wojskowa współpraca na zasadzie dobrowolności będzie znaczącym czynnikiem wzmacniającym polityczne i gospodarcze stosunki i dlatego Rada Ministrów uważa za celowe:

1. Zapewnić czechosłowackim ochotnikom wszystkie przywileje, które mają ochotnicy rosyjscy.

2. Przydzielić działki tym Czechosłowakom, którzy po skończeniu swojej wojennej aktywności chcieliby pozostać na Syberii ${ }^{37}$.

P. Wołogodski skontaktował się też z przedstawicielami czechosłowackiego wojska w Omsku, z którymi kilkakrotnie rokował o włączeniu czechosłowackich jednostek do armii Kołczaka ${ }^{38}$. Rząd A. W. Kołczaka jesienią 1919 roku znalazł się w trudnej sytuacji. Jeśli chciał utrzymać swoje pozycje w zachodniej Syberii, potrzebował pomocy czechosłowackich wojsk. Z tego powodu podczas październikowych rokowań Syberyjski Rząd Tymczasowy był skłonny pójść na różne ustępstwa, aby tylko zapobiec swojemu upadkowi ${ }^{39}$.

${ }^{35}$ DMČSSV. D. I., s. 271.

${ }^{36}$ DMČSSV. D.I., s. 293.

${ }^{37}$ DMČSSV. D. I., s. 311.

38 За спиной Колчака. Документы и материаль, с. 250.

${ }^{39}$ Potwierdza to także telegram przedstawiciela czechosłowackiego wojska w Omsku z dnia 29.10. 1919 roku do pełnomocnika czechosłowackiego rządu w Rosji B. Pavla: „Sukin mi oznajmił, wczoraj rada ministrów pod przewodnictwem A. W. Kołczaka przyjęła wszystkie nasze ewentualne żądania na wypadek naszego wystąpienia, o którym rozmawiałem z Wologodskim (utrzymanie przez cały rok, żołd żołnierzy w złocie, korzyści w nabywaniu majątku, działalność handlowa, eksport towaru dla naszych fabryk itd.). Są chętni zgodzić się na 
Pozycja rządu A. W. Kołczaka na końcu października 1919 roku zaczęła słabnąć zarówno w wyniku wzmożonej ofensywy Armii Czerwonej, jak też ataków partyzantów na tyłach. W listopadzie 1919 roku armia Kołczaka zaczęła ustępować w kierunku wschodnim. Dnia 13 listopada 1919 admirał Kołczak opuścił Omsk i udał się do Irkucka. O rozwoju sytuacji na Syberii Bohdan Pavlu szczegółowo informował ministra spraw zagranicznych CSRN, E. Beneša, w telegramie z dnia 17 listopada 1919 roku:

Sytuacja armii Kołczaka jest katastrofalna. Siły bolszewików niewielkie, ale moralny upadek wojsk syberyjskich w wyniku rozpadu i krótkowzroczności rządu jest zbyt duży. Dla nas powstała nowa i trudna sytuacja, dlatego że grozi niebezpieczeństwo zetknięcia się z bolszewickim frontem. Zaproponowaliśmy w Omsku wprowadzić parlamentarny reżim w celu ratowania sytuacji, odpowiedzieli jednak, że teraz nie ma kiedy. W ten sposób rząd Kołczaka podpisał swój upadek ${ }^{40}$.

Dowództwo czechosłowackich jednostek doskonale uświadamiało sobie złożoność sytuacji i starało się zabezpieczyć odejście jednostek z rosyjskiego terytorium. Część wojskowego dowództwa od początku rządów gabinetu admirała A. W. Kołczaka nie ukrywała swojego zaniepokojenia związanego z objęciem przez niego władzy i sposobem rządzenia. Ich poglądy były w wielu punktach identyczne z poglądami prawicowych eserowców i liberalnych politycznych przywódców przebywających na Syberii.

Ze względu na to, że dowództwo Legionu Czechosłowackiego nie znajdowało porozumienia z rządem admirała Kołczaka, zaczęło coraz bardziej otwarcie popierać aktywizujące się opozycyjne ugrupowanie eserowsko-liberalne. Rozwój wydarzeń zaostrzył się najpierw we Władywostoku, gdzie we wrześniu 1919 roku doszło do powstania przeciwko Kołczakowi. Powstanie przygotowały eserowskie i liberalne kręgi, które uzyskały poparcie nie tylko od przywódców czechosłowackich wojsk we Władywostoku, ale też przywódców Ententy, głównie USA, którzy kontrolowali sytuację w regionie ${ }^{41}$. Opór wobec rządu Kołczaka stopniowo przenikał z Przymorskiego Obwodu także do zachodniej Syberii i samego Irkucka, w którym od listopada 1919 roku rząd ten miał siedzibę.

Rada ministrów rządu Kołczaka na swoim posiedzeniu w dniu 23 listopada 1919 roku zajmowała się przede wszystkim sytuacją w guberni irkuckiej, ale wiele uwagi poświęciła też wydanemu przez przywódców Legionu Czechosłowackiego oświadczeniu, w którym potępiali politykę rządu Kołczaka i twierdzili, że jedynym wyjściem z tej nadzwyczajnej sytuacji jest zrzeczenie się przez admirała Kołczaka tytułu naczelnego dowódcy. Postulowali również zwołanie zgromadzenia ustawodawczego i rekonstrukcję rządu ${ }^{42}$. W następnych dniach syberyjski rząd, aby wybrnąć z tych trudnych okoliczności, kilkakrotnie wracał na swoich posiedzeniach do oceny stosunków z Legionem Czechosłowackim ${ }^{43}$.

Przedstawiciel Ministerstwa Spraw Zagranicznych w rządzie syberyjskim, I. I. Sukin, informował przedstawiciela rządu syberyjskiego w Paryżu, S. D. Sazonowa, o sytuacji w Irkucku i zmianie stanowiska czechosłowackich wojsk:

\footnotetext{
wszystko i przyjąć nasze żądania. Proszę przyjechać do Omska i porozumieć się z nimi. Nigdy nie było tak korzystnego czasu dla Czechów jak teraz”. In: DMČSSV. D.I., s. 312.

${ }^{40}$ DMČSSV. D. I., s. 316.

${ }^{41}$ DMČSSV. D. I., s. 310.

42 За спиной Колчака. Документы и материаль, Москва 2005, с. 258.

43 За спиной Колчака. Документы и материаль, Москва 2005, с. 259.
} 
Grożące nadejście bolszewików wywołało niepokój wśród Czechów, którzy zostali dyslokowani wzdłuż kolei i boją się konsekwencji swojego uczestnictwa. Niektórzy z nich myślą o tym, że natychmiast odejdą na wschód i pozostawią kolej swojemu losowi. Polityczny przywódca Czechów, doktor Girsa, ma tendencje postępować solidarnie z miejscowym antyrządowym żywiołem. Czesi tu wystąpili z oświadczeniem, że ich pozycja jest nie do zniesienia i że koniecznie trzeba skończyć z neutralnością, której do tej pory dotrzymywali w rosyjskich wewnętrznych zależnościach. W istocie wszystkie ich sympatie są po stronie socjalistycznych ugrupowań, które przygotowują w Irkucku powstanie ${ }^{44}$.

Rozwój wypadków nie przyniósł jednak uspokojenia i rozwiązania politycznego kryzysu. Wprost przeciwnie, ostra reakcja A. W. Kołczaka na czechosłowackie oświadczenie, opublikowana 25 listopada 1919 roku i adresowana do przywódców Legionu Czechosłowackiego, jeszcze bardziej zaostrzyła sytuację. W odpowiedzi admirał Kołczak napisał:

Nie mogę uważać czeskiego memorandum podpisanego przez Girsę i Pavlu za dokument, który wyraża stanowisko czeskiego rządu albo czeskiego wojskowego dowództwa. Odbieram to memorandum jako akt, za który są odpowiedzialni tylko Girsa i Pavlu, którzy samych siebie uważają za czeskich przywódców. Memorandum oceniam jako akt politycznej intrygi i szantażu. Jeśli chodzi o możliwość takiej interwencji, oświadczam, że jakiekolwiek kroki w tym kierunku będą uważane za nieprzyjacielskie działanie, które faktycznie wspiera bolszewików, i odpowiem na nie zbrojną siłą. Jeśli chodzi o osoby, które podpisały memorandum, dałem rządowi dyspozycje, aby z nimi przerwał kontakty i przedłożył czeskiemu rządowi żądanie odwołania tych osób z Rosji ${ }^{45}$.

Zrealizowanie tego zarządzenia ani admirałowi Kołczakowi, ani jego rządowi już się nie udało. Zaczęły się ostatnie dni rządu admirała A. W. Kołczaka na Syberii.

$\mathrm{Na}$ początku stycznia 1920 roku admirał A. W. Kołczak poprosił przywódców Ententy o ochronę. Ententa powierzyła to zadanie Legionowi Czechosłowackiemu. Wówczas przywódcy irkuckiego Sowietu zażądali od legionistów wydania A. W. Kołczaka, od czego uzależniali umożliwienie żołnierzom czechosłowackim udania się do Władywostoku.

Wówczas admirał A. W. Kołczak został wydany irkuckim bolszewikom, którzy stracili go 7 lutego 1920 roku $^{46}$. Po zabiciu Kołczaka już tylko zabajkalski ataman Siemionow stanowił w okolicy Czyty znaczącą antysowiecką siłę. Do końca 1920 roku bolszewicy umocnili swoje pozycje także w tej części Rosji i rozszerzyli swoją władzę na terytorium całej Syberii, natomiast Legion Czechosłowacki opuścił Syberię i terytorium Rosji.

(Przekład: dr Bożena Kotuła)

${ }^{44}$ DMČSSV. D. I., s. 320.

${ }^{45}$ DMČSSV. D. I., s. 321-322.

${ }^{46} \mathrm{Z}$ prac poświęconych admirałowi Aleksandrowi W. Kołczakowi: В. Е. Максимов, Звезда адмирала Колчака, Минск 1991; Н. А. Черкашин, Звезда Колчака. Размылиления над старыми фотографиями, Москва 1993; И. Ф. Плотников, Александр Василиевич Колчак; жизнь и деятельность, Ростов на Дону 1998; Н. А. Черкашин, Адмирал. Трагическая судьба Колчака, Москва 2009. 


\section{Bibliografia}

Dokumentacja archiwalna:

Государственный архив Российской федерации (дальше ГАРФ), Москва.

ф. 185, оп, 1. д. 2.

ф. 175, оп. 1. д. 14.

Dokumenty publikowane:

За спиной Колчака. Документы и материалы, red. А. В. Квакина, Москва 2005.

Культурно-национальная автономия в истории России. Документальная антология, Т. I,

Сибирь 1917-1920, red. Э.Ю, Черняк, Томск 1998.

Сводный каталог периодики русского зарубежья:

Вольная Сибирь, Прага 1927, кн. 2.

Вольная Сибирь, Прага 1928, кн. 3.

Monografie:

Гинс Г. К., Сибирь, союзники и Колчак. Поворотный момент русской истории 1918-1920, впечатления и мысли члена Омского правительства, Москва 2007.

Максимов В. Е., Звезда адмирала Колчака, Минск 1991.

Плотников И. Ф., Александр Василиевич Колчак; жизнь и деятельность, Ростов-на-Дону 1998.

Сватников С. Г., Россия и Сибирь. (К истории сибирского областничества в 19. веке), Прага 1929.

Черкашин Н. А., Адмирал. Трагическая судьба Колчака, Москва 2009.

Черкашин Н. А., Звезда Колчака. Размылиления над старыми фотографиями, Москва 1993.

Шишкин Б. И., Москва - Сибирь. История взаимоотношений (1917-1933). История Сибири: человек, общество, государство, Новосимбирск 1995.

Artykuły:

Всероссийское Учредительное собрание и демократическая альтернатива. Два взгляда на проблемы, Отечественная история, 1993, н. 5.

Журавлев В. В., Симонов Н. С., Причины и последствия разгона Учредительного собрания, Харьков 1918, Вопросы истории 1992, н. 1.

Тимонина Н., Сибирьское областничество (60-е г2. ХІХ в. - 1920 г., Глубинка 1995, н. 1.

Фирсов Е. Ф., Милан Растислав Штефаник в России. (По опертивным материалам иарской и колчаковской власти, [в:] Новый взгляд, Neografia Martin, Slovakia 2001.

\section{Alfabet laciński}

Dokumenty publikowane:

Dokumenty a materiály k dějinám československo-sovětských vztahu. Díl I. (november 1917-august 1922), Praha Academia 1975, (d’alej len DMČSSV).

Monografie:

Harbul'ová L', Sibirsky autonomizmus. Zdroje, prejavy, reflexie (1917-1939), Praha 2010.

Pichlík K., Klípa B., Zabloudilová J., Českoslovenští legionáři (1914-1920), Praha 1996. 
Lubica Harbul'ová, Doc. PhDr., CSc., obecnie pracuje w Instytucie Historii na Wydziale Sztuk Uniwersytetu Preszowskiego w Preszowie na Słowacji. W swoich badaniach skupia się na historii Rosji i Europy Wschodniej w XX wieku. Opublikowała wiele prac dotyczących problemów rosyjskiej emigracji w Czechosłowacji okresu międzywojnia oraz stosunku „,białych” Rosjan do Europy Środkowej. Jest autorką trzech monografii, ostatnio opublikowała Sibirsky autonomizmus. Zdroje, prejavy, reflexie (1917-1939), Praha 2010. /Siberian Autonomism. Sources, symptoms, reflections (1917-1939), Prague 2010. 